\title{
Widening The Digital Divide: A Study On The Possible Impact Of The Convergence Bill Of 2003 On The South African Cybereconomy

\author{
E M da Silva
} \\ Admitted Attorney \\ C J Kruger \\ Department of Informatics, University of Pretoria
}

\begin{abstract}
Business does not exist in a vacuum. The external environment is either conducive to or stifles business growth. Van Rooyen (2004: 399) points out that 'E-business has important implications for South Africa as an emerging economy, as it creates the possibility of better access to various financial resources and eventually increased economic activity. This will affect all sectors in the economy and may lead to generally improved business infrastructure for the country as a whole and for individual business, local authorities and government treasury departments. This is especially important for South Africa as a developing country, which, in turn, will make an important contribution to rapid alleviation of private and more rapid reform in the long run'. A major determinant of the external environment in which business operates is legislation and regulation. It therefore follows that any regulation or legislation pertaining to E-business must be conducive to growth. The draft Convergence Bill of 2003 is to be tabled in Parliament during its next session. In this paper it is argued that, in its present form, the proposed Convergence Bill is in fact detrimental to organisational growth, a potential kiss of death for E-enabled organisations.
\end{abstract}

Abstract

Key words: Convergence Bill, cybereconomy, digital divide, organisational growth, E-enabled organisations.

JEL K3, K39

\section{1}

\section{Introduction}

'Computer networks are the communication basis of the information age, and they will change, or are already changing, the whole of the world economy and therefore the structure of world society. From the point of view of national governments they are an almost terminal threat.' (Davidson \& ReesMogg, 1998: 6)

The new information age has brought about a shift in power. Networks, the free exchange of information through the cybereconomy and ebusiness have resulted in a lack of government control over the exchange of content and the flow of money, and governments are taking action to regain control. More international connectivity is also enabling citizens to inform the international community more readily of abuses within a country, thus enabling the international community to act more rapidly. However, as Yeomans (1999: 423) states, 'It is particularly ironic that countries which stand to benefit most from technology which eliminates distance as a barrier to development may be precisely those least likely to gain access to it'. Internationally, there is a definite divide between 'North' and 'South' in which 'North' refers to the developed countries connectively enabled and 'South' refers to the countries not connectively enabled.

In the delivery of Theme Four (Maximising the benefits: Economic and Social Impacts) of the government's e-commerce strategy 
document, government defines this digital divide as follows:

'Digital divide refers to inequalities in the distribution of ICTs between developing and developed economies. The "North-South" digital divide is real and needs to be addressed. It also refers to the gap in the information sphere between the most developed parts of the country and underdeveloped rural parts, including disadvantaged groups. The challenge is how to narrow down the gap between "information haves" and "information have-nots" through addressing inequalities and inequity. If this matter is not urgently addressed, the benefits of e-commerce will be enjoyed by only the few and the expansion of e-commerce would indeed contribute to broaden rather than reduce a possible digital divide' (RSA Government Policy, 2004). The challenge is therefore for 'South' countries, South Africa included, to bridge the digital divide and establish closer connectivity with the 'North'.

Laws of countries either enhance or thwart business (Samuelson \& Nordhaus, 1995). Not only is it pertinent to analyse relevant regulation impacting on connectivity, but also to question the relevance of regulations. If a law is promulgated that has no way of being enforced or if the enforcement thereof calls for such draconian measures that more damage is done to law-abiding citizens by enforcing the law than by leaving them alone, then one must question the very validity of the law. The Department of Communications has embarked on a strategy to enable South Africa to transcend the digital divide. Certain Acts have been promulgated to implement this strategy. Since numerous Acts regulate the communications sector in South Africa, and as a result of the convergence of technology, the Department of Communications published the draft Convergence Bill, 2003 on 3 December 2003 (Minister of Communications, 2003). It is against this backdrop that the South African Convergence Bill must be assessed. There can be no quarrel with the aim of the Bill: 'to enhance connectivity and narrow the digital divide'. However, the proposed implementation of the Bill needs to be analysed and propositions need to be measured against critical success factors (factors that must be in place in order to successfully establish a booming cybereconomy) before it can be discerned whether or not the desired outcome will in actual fact be achieved. It is the author's belief that the degree to which government supports or thwarts the growth of the cybereconomy will be in direct correlation to the impact of regulation that applies to the cybereconomy.

Prior to the publication of the draft Bill, a colloquium was held during July 2003 to canvass role players' input as to what should be contained in the said Bill. Although many role players commented on the proposed Bill, not all the existing concerns were raised, nor were all the issues addressed. Government responded extremely negatively to concerns raised, in many cases neglecting to address vital issues in the draft Bill. The aim of this article is therefore to determine whether or not the Bill, if passed in its present form, will in fact assist South Africa to transcend the digital divide.

In order to determine whether or not the Convergence Bill, if passed in its present form, will in fact help South Africa to bridge the digital divide, the following aspects need to be covered:

- the mechanism of the cybereconomy,

- government's role in establishing a cybereconomy,

- the effect of legislation on the growth of the cybereconomy,

- the South African cybereconomy (threats, opportunities),

- the proposed Convergence Bill of 2003 in perspective.

Finally, all facts, findings, arguments and recommendations presented in this article are summarised in a conclusion on the impact of the proposed Convergence Bill of 2003 on the South African cybereconomy. 
2

\section{Research methodology}

The methodology used is non-empirical and qualitative in nature. Articles sourced from academic journals formed the largest part of the investigation into the critical success factors needed to establish a successful cybereconomy and also the threats facing the global cybereconomy. For an understanding of the South African government's strategy in narrowing the digital divide, the Green Paper on e-government was meticulously scrutinised and analysed. To understand the stakeholders' objection to the proposed Convergence Bill of 2003, permission was sought from Mobile Telephone Networks (MTN) to peruse their submission on the Convergence Bill. The Internet Service Providers Association of South Africa (ISPA) also commented on the Bill and their submission was accessed via their website. Although the Convergence Bill was published on 3 December 2003, it has not yet passed into law and numerous articles from concerned stakeholders have been published in various newspapers in South Africa; these newspaper articles were also consulted.

\section{3}

\section{Assumptions and limitations}

The categories of content subject to legal debate are numerous and each category warrants a research paper on its own ${ }^{1}$. As this research paper is written from a managerial perspective and not a legal one, it was not possible to discuss all the legal issues relating to content on the cybereconomy. In essence, only principles of regulating access to content and content itself, but not categories of content, are discussed. The fact that the Convergence Bill of 2003 has not yet been passed places a limitation on the findings of this article. However, it is presumed that the Convergence Bill, as published on 3 December 2003, will become legislation in its present form. The presumption is therefore made that the threats advocated will in fact be carried through if the Bill is passed in its present form.
4

The mechanism of the cybereconomy

In order to understand the issues that determine connectivity, it is essential, first of all, to have an understanding of how the cybereconomy works and what physical attributes are needed to give effect to a platform for a flow of information. The cybereconomy has many layers that ensure connectivity. The physical infrastructure is made up of networks, including the cables and networking of those cables; the physical equipment, inclusive of computers and software to access information; and the actual data, which is the subject of the flow of information. All these layers have an impact on the connectivity of users of the cybereconomy. Depending on the state and compatibility of the various layers, connectivity is or is not effective. Arguably, it is this connectivity that forms the basis of the gulf between 'North' and 'South' (Wainright Martin et al., 2005). In order to bridge the 'digital divide', the role of government is crucial. It may be argued that not all governments are placed in power via a democratic process. Be that as it may, the reality is that governments govern because the majority of the population within the national borders are willing to tolerate the powers that be. The government is placed in a fiduciary position over the population and as such should act in the best interests of that population - which may sometimes conflict with the best interests of the government in power.

\section{5}

\section{Governments' role in establishing a cybereconomy}

According to the World Bank, connectivity is a prerequisite for development and funding (Westphal, 1998). In this context, Westphal argues that it is crucial that governments set an example by e-enabling government departments. Government should therefore act in a fiduciary capacity to ensure the development of connectivity. Westphal emphasises that content and infrastructure access should be 
ensured free of monopolies and artificial barriers, including regulations, that deny connectivity. Paramount in this process are telecommunications networks - the backbones of connectivity. Power struggles for ownership of lucrative telecommunications networks must therefore be fairly addressed. According to Main (2001), monopolies in the telecommunications sector must be eradicated as they preclude investment and result in inflated connectivity costs.

As culturally sensitive as language issues may be, a universal language is needed to ensure connectivity. English is the predominant language of connectivity and a trade-off between connectivity and language protection is necessary (Main, 2001). Arguably, the advantage of connectivity outweighs the argument of a starving population bent on protecting their language and forsaking connectivity.

Governments that are not forward-looking as regards their skills shortage in the connectivity sphere will pay a heavy price in terms of 'brain drain' and telecommunications systems that are not sustainable. According to De Roy (1997), the argument regarding prioritising of food and running water to the detriment of connectivity is merely a short-term solution that will ensure a continued slide into abject poverty. In the South African context, government must therefore ensure that primary, secondary and tertiary educational curricula are adapted to ensure a narrowing of the skills shortage and hence a narrowing of the digital divide.

\section{6}

\section{The effect that legislation has on the growth of the cybereconomy}

Legal disciplines have a long history. Since time immemorial, laws have been adapted to serve the nations that have adopted them. As nations modify their laws to complement their own special brand of culture, religion and morality, no uniform set of laws exists. The very nature of connectivity, being ubiquitous and transcending national borders, renders any form of uniformity, especially in substantive and procedural laws, unproductive. The sheer volume of transactions over the Internet renders the application and enforcement of national laws unrealistic. Of interest is the fact that the 'South' countries over-regulate all aspects of the cybereconomy, whereas the countries of the 'North' regulate to encourage free-market principles and ensure the free flow of information, opting for self-regulation regarding content of data.

Estache (2002) is therefore of the opinion that it is regulation in the form of monopolies and social requirements in the telecommunications sector, in particular, that impacts on investment. It stands to reason that monopolies in the telecommunications industry will result in prohibitively expensive connectivity, leading to a widening of the digital divide. In essence, regulation of Internet accessibility filters down to end users being denied connectivity based on costs and political pressures. What this boils down to is that regulating content and the free flow of information is nothing other than censorship, stunting connectivity in countries that desperately need to be part of the global village.

\section{7}

\section{The South African cybereconomy}

Although South Africa can be considered a leader in Africa, the country is, for the most part, classifiable as 'South' in the digital divide. The infrastructure needed to support the network of the cybereconomy is technologically inept compared to the networking of the 'North'. This is partly due to the fact that the telecommunications sector in South Africa is, notwithstanding the Department of Communications licensing a second network operator on 18 September 2004, monopolistic in nature, with Telkom SA being the only operating telecommunications network system in South Africa. What exacerbates the problem still further is that access to the telecommunications infrastructure via an Internet Service Provider (ISP) is prohibitively expensive due to price hikes by Telkom for connectivity, resulting in 
ISPs having no option but to filter costs of connectivity down to users. Personal computers (PCs) are mostly imported and, due to the fluctuation of the South African currency, prices are considered to be prohibitively expensive.

The mere fact that no lessons have been learned from other 'South' division countries, to wit placing societal price tags on connectivity, entrenches South Africa firmly in the 'South' division. Notwithstanding the licensing of the SNO on 18 September 2004, Stones is of the opinion that the ability of the SNO is in question due to a lack of investment, among other things (Stones, 2004). Arguably, this lack of interested investors is due to government's demands for societal paybacks. According to Gartner, to expect an international investor to address poverty alleviation is counterintuitive. He argues that the business of business is business and the aim is always to make a profit (Gartner, 2003). International investors have, on numerous occasions, indicated that they are not convinced that $\mathrm{BEE}$ is a panacea for poverty and the path to wealth redistribution. BEE will not be seen as an investment opportunity as long as BEE partners are not appointed on merit. Investors are also concerned that there is no indication that the IT skills shortage is being addressed seriously by the government in South Africa, with the academic standards at primary, secondary and tertiary level being lowered to address past inequities rather than being futureorientated to ensure survival in the new cybereconomy. Therefore, in the South African context, as long as know-how is dependent on international handouts, investment in the South African cybereconomy will not be sustainable. The lack of relevant skills could sentence South Africans to remaining mired in the 'South' division of the digital divide. In South Africa, a number of the critical success factors for establishing a successful cybereconomy are still lacking.

\section{8}

\section{The proposed Convergence Bill of 2003 in perspective}

Legal certainty reduces risk for the business community. Considering the desperate need for investment in the telecommunications sector, clarification in legislation would be appreciated. As stated earlier, as part of the strategy purportedly aimed at narrowing the digital divide, the Convergence Bill of 2003 was published on 3 December 2003. The central question remains whether or not the Convergence Bill, if promoted in its current form, will indeed enhance the critical success factors needed for establishing a successful cybereconomy. Since publication, the Convergence Bill has evoked strong comments. According to Buys, the Convergence Bill of 2003 is riddled with ambiguity and uncertainty (Buys, 2004). It is argued that an Act to accomplish convergence legislation in the telecommunications sector, and thus replace existing Acts, should occur as a result of market forces coming into play in a liberalised telecommunications sector (MTN, 2005). Taking into account the Telkom monopoly, this is clearly not the case in South Africa. It is thus argued that the Bill is premature and will adversely affect future evolution and liberalisation of the telecommunications sector (MTN, 2005).

A further concern is the socialist flavour of the Bill, with the aim of connectivity articulated as safeguarding, enriching and strengthening the cultural, political, social and economic fabric of South Africa. As has been argued, connectivity does not have a political agenda and no regulation should attempt to enforce one. Cultural enhancement is problematic in a culturally diverse country such as South Africa, and the issue of whose culture should be enhanced is naturally fraught with controversy. To promote political, cultural, social and economic agendas in one piece of legislation seems counterintuitive and doomed to failure. The fall of communism is a telling example.

In terms of the maxim of the rule of law, separation of powers is conducive to equity and a levelling of the playing fields between government and the private sector. According to Berger, the Convergence Bill does not facilitate separation of powers, but goes further and grants more powers to the Minister of Communications than she had prior to the proposed Bill (Berger, 2004). It can be argued 
that there is no place for bureaucrats in the regulation of the cybereconomy: As early as 1993, Bos pointed out that: 'any meaningful discussion of market reforms in this (telecom) sector must begin with the question of creating a credible and efficient regulatory mechanism. This is important because many observers remain sceptical about the ability of a bureaucracy to deliver'. Bos goes on to say that: 'A priori, it is not clear why the state, failing to run the firms well as (an) owner, should now suddenly become an efficient regulator' (Bos, 1993). In agreement with the statements made by Bos, Ayogu and Hodge maintain that: 'To us, the explanation lies in recognizing that regulators are often political actors themselves or serve at the behest of those in political office. The question then is under what conditions these technocrats become powerful' (Ayogu \& Hodge, 2002).

The most obvious shortcoming of the Convergence Bill lies in the issue of licensing. Much confusion reigns over the issuing of the licences and the categories of licences that exist. The fact that the Bill is interpreted as stating that website owners need a licence has caused panic among South African cybereconomy users.

According to Berger, 'When one reads these sections (Chapter three) together, the following picture emerges. To start with, it can be noted that the Bill specifies as different license types

- Type One: only "individual licences" can be issued for infrastructure and network provision.

- Type Two: only "class licences" can be issued to content providers.

- Type Three: individual or class licences can be allocated for other kinds of applications (e.g. directory services' (Berger, 2004: 6).

Apart from licence types, ISPA emphasises that there are also four licence classes: 'Infrastructure Service, Communications Network Service, Communications Applications Service and Communications Content Service ... It seems as if there are multiple licences that can be issued within each category but this is not clear from the Bill' (ISPA, 2004: 3). Thus within the four classes mentioned by ISPA, the three types of licences mentioned by Berger can be issued.

The confusion is exacerbated further by the fact that 'Individual licences are envisaged for Infrastructure and Communications Network Services. Class licences are envisaged for Communications Content Services. Communications Applications Services seem to fall within both categories of license, so presumably some types of Communications Applications Services would require class licences, while others would require individual licences' (ISPA, 2004: 4).

Berger (2004: 6) goes on to say that it is not clear where 'traditional broadcast service' and 'on-line publishing and information services' fit into these categories. It would seem that this depends on the interpretation of content services or application. Berger thus leaves the application to websites (on-line publishers) open to interpretation, but he argues that, if one reads other sections of the Act, a distinction is in fact drawn between on-line publishers and the licensing of content provision. However, he does concede that the situation needs to be clarified and the legislature should be clear on whether websites need to be licensed (Berger, 2004). Buys (2003) $)^{2}$ interprets the Act as meaning that all websites may need a licence. Given that the penalty clause in the Bill makes unlicensed distributors of on-line content liable for fines as high as R500 000 or R10 000 per day, one can understand the need for clarity.

The On-line Publishers Association (OPA) is of the opinion that the provisions of the Bill 'will hit thousands of ... individuals, corporate entities, and public bodies including many small and medium enterprises which market their services on the internet' (Emdon, 2004). The OPA therefore feels that this could become a constitutional issue, i.e. discrimination against on-line publishers, given that off-line publishers do not require a licence. The OPA therefore warns that the Bill will stifle the development and provision of on-line content of all associated businesses and organisations. According to Emdon (2004), sixteen top publishers have already declared that, should the Bill be passed, they will move their operations offshore. Moreover, these publishers also aver that the Convergence Bill is aimed at controlling 
cybereconomy content rather than dealing with the convergence of technology.

Reacting to the furore over the licensing of websites, 'Minister Ivy Matsepe-Casaburri said in an impromptu news briefing that some issues raised reflected misunderstandings. The idea that website owners would be required to register their websites was one example of the misunderstandings' (Emdon, 2004). However, to date no official statement from the Department of Communications has been made on the issue of licensing.

It should be noted that jurisdiction over a website is vested in the hosting of the site. Should a country pass laws that are not favourable to the site owner, the movement of the site to another country is merely a mouse-click away. In cases where site owners move hosting en masse, ISP will be denied revenue, resulting in closure. According to Webcheck, South Africa is nearing such a point - the connectivity of South Africans has increased marginally from 1:15 to $1: 13$ over the past twelve months. (What is holding back Internet growth in South Africa?)

\section{9 \\ Conclusion and recommendations for the future}

In this article it is argued that the weaknesses in the South African telecommunications sector are vast, but should not be viewed as insurmountable. The primary concern should be the liberalisation of the telecommunications sector with more than lip service being paid by the Minister of Communications in issuing the SNO. The SNO needs to become operational, not merely licensed. Thereafter, the issue of access to equipment for connectivity should be researched and the tariffs and import duties on PCs and other equipment addressed. IT skills and education must be institutionalised with less emphasis being placed on addressing political issues of the past and more emphasis on future survival and growth in South Africa. After ten years of democracy, gnawing the old colonial bone is growing tedious and the international community is viewing Africa more as a bottomless pit than an investment opportunity. Africans should start accepting responsibility for their own survival and stop relying on handouts from the developed world. The cybereconomy is a unique opportunity to catapult our country into the new economy and it should be grasped with both hands.

With due regard for the draconian penalty, R500 000 or R10 000 fine per day for noncompliance, it would be prudent for the legislative body to first clarify the many aspects dealing with licensing in terms of the Bill. With the enactment of the Convergence Bill of 2003 in its current form, an exodus of web hosting will result, giving the kiss of death to the cybereconomy in South Africa.

\section{References}

1 AYOGU, M. \& HODGE, J. (2002)

"Understanding telecommunication sector reforms in South Africa: A political economy perspective", Journal of Contemporary African Studies, 2(20): 275.

2 BERGER, G. (2004) Submission to the Portfolio Committee on Communications, Department of Communications, g.berger@ru.ac.za, Grahamstown, 03 February 2004.

3 BOS, D. (1993) "Privatization in Europe: A comparison of approaches", Oxford Review of Economic Policy, 9(1):95.

4 BUYS, R. (2004) Submission on the draft Convergence Bill, e-mail from reinhardt@buys.co.za, to The Department of Communications, Cape Town, 06 February 2004.

5 DAVIDSON, J.D. \& REES-MOGG, W. (1998)

The sovereign individual 1st ed., Pan Books: London.

6 DE ROY, O.C. (1997) "The African challenge: Internet networking and connectivity in a developing environment", Third Quarterly, 1(5):883-898.

7 EMDON, C. (2004) "Online groups slam retrograde”. [Online]. Available: http:/ www. suntimes.co.za/2004/02/22/business/ technologytech03.asp. Accessed: July 2004.

8 ESTACHE, A.; MANACORDA, M. \& VALETTI, T.M. (2002) "Telecommunication reforms, access regulation, and Internet adoption in Latin America", [Online]. Available: www.worldbank.com. Accessed: March 2002. 
9 ISPA - INTERNET SERVICE PROVIDERS' ASSOCIATION. (2004) "Comments on the Convergence Bill”, [Online]. Available: www.ispa.org.za. Accessed: July 2004.

10 MAIN, L. (2001) "The global information infrastructure: Empowerment or imperialism?", Third World Quarterly, 22(1).

11 MINISTER OF COMMUNICATIONS, THE. (2003) December 03, The Convergence Bill, No. 3382 .

12 MTN (2004) MTN submission on Convergence Bill, dd. 3 February 2004, e-mailed 05 June 2004.

13 RSA GOVERNMENT POLICY (2004) "Theme 4 - Maximising the benefits: Economic and social impacts", [Online]. Available: http:/ www.polity.org.za/html/govdocs/green_papers/ greenpaper/ theme4. html. Accessed: March 2004.

14 SAMUELSON, P.A. \& NORDHAUS, W.D. (1995) Economics, 15th ed. McGraw-Hill: New York.

15 SOCIKWA, K.X.T. (2004) "No rush in search for SNO major investor", Business Day, September 19:3.

16 STONES, L. (2004), "Bid for rival to Telkom in shambles”, Business Day, March 17:1.

17 GARTNER GROUP (2004) "South Africa Telecom Companies: Caught in a cultural warp?" [Online]. Available: http://gartner.com. Accessed: August 2004.

18 THE GOLDSTUCK REPORT (2004) "Internet Access in South Africa 2004". [Online]. Available: http://www.theworx.biz/access03.htm. Accessed: 26 August 2004.

19 VAN ROOYEN, J. \& REITSMA, W. (2004) "The future of e-business on treasury and risk management systems and treasury management in South Africa", Development Southern Africa, 21(2):399-414.

20 WAINRIGHT MARTIN, E.; BROWN, C.V.; DE HAYES, D.W. \& HOFFER, J.A. (2005)
Managing Information Technology, $5^{\text {th }}$ ed., Prentice Hall: New Jersey.

21 BUYS INC (2004) "Welcome to the Stop the Convergence Bill campaign", [Online]. Available: www.buys.co.za Accessed: 3 March 2004. Article author(s) not cited. Article published under the hospice (ownership) of "Buys Inc" attorneys at law.

22 WESTPHAL, H. \& TOWELL, E. (1998) "Investigating the future of cybereconomy regulation", Electronic Networking Applications and Policy, 8(1).

23 WEBCHEK (2004) "What is holding back Internet growth in South Africa?" [Online]. Available: http://www.webchek.co.za/ library_holdback.html. Accessed: 26 August 2004. Webchek is an electronic newsletter - no author(s) Available: http://www.webchek.co.za/ library_holdback.html. Accessed: 26 August 2004.

24 YEOMANS, K. (1999) "Commonwealth island states in the global information society: A narrow window of opportunity", The Round Table, 351(1):423.

\section{Endnotes}

1 For example, categories subject to legal scrutiny include copyright and the Internet, trademarks, domain names and meta tags, cybereconomy and e-commerce patents, electronic transactions, cryptography and authentication, on-line consumer protection and spam, privacy and the Internet, freedom of expression and the Internet, taxation and e-commerce, criminal law and the Internet, on-line dispute regulation, and on-line credit card payments, to name but a few.

2 Buys, an attorney specialising in e-commerce. 